\title{
Borders and Possibilities of Foreign Policy of the Small State on the Example of Kyrgyzstan
}

\author{
Bekbolot kyzy Cholpon \\ People's Friendship University of Russia, Moscow, Russia
}

\begin{abstract}
In this article is shown all the process which is happening at the moment in the globe. How big countries may influence to the small countries such as Kyrgyzstan. Some approaches that are used for achieving results. Also were taken into account researches of some scientists. Kyrgyzstan is young, small independent country with democratic ideas for running country. The research focus on the whole situation in the country and in the globe, trends. The research methods used from the famous world scientists their findings, participation at the international conferences dedicated to the international diplomacy and etc. The main conclusions small independent country has to follow world trends and collaborate mutually with all countries.
\end{abstract}

Keywords: foreign policy, small state, pawns, superpower, physical survival, globalization

\section{Introduction}

The population of Kyrgyzstan makes nine percent of the total population of the Central Asian and 0.08\% population of the Globe. Kyrgyzstan's territory makes five percent of Central Eurasia and $0.1478 \%$ of the Universe. Kyrgyzstan is land locked country. It is bordering with other three countries which do not have access to the ocean such as Kazakhstan, Uzbekistan and Tajikistan. The border length is $4104 \mathrm{~km}$, out of this 1051 km Kazakhstan, 870 km Tajikistan, 1099 km Uzbekistan.

Kyrgyzstan is a tiny country, with tiny population and weak potential, which is not enough to provide security for its own resources and not presents danger for safety. Also country don't possess enough influence to international level and with weak economic military potential. Independence of the country and full territory. Common criteria's small countries do not have. R. Rostine main feature small countries possess lack of resources and indeed cannot do at the world's level, that is why external support is necessary for its safety. Jake considers small country which cannot protect its policy, national interests neither on the national level or world level. By the theory of Goldmaher small country - any country which is left aside from world business.

Introduction by Kyrgyz in 19th century patriarchal nomad life style and managing, which did not require construction of cities, villages, roads, irrigation channels, agriculture and etc., created enormous visible free empty and settled land. Since the declaration of Kyrgyz land as a property of Russian empire from 1868 to 1883, the northern Kyrgyzstan actively moving Kazaks and farmers with the purpose to create stable social population and to strengthen it's position in the region. From 1891-1892 moving was done despite bad yield and hunger (Suyunbaev, 2005). Geopolitical grounds of development and security of Kyrgyzstan: global,

Bekbolot kyzy Cholpon, master student, Department of Theory and History of International Relations, People's Friendship University of Russia. 
regional and national aspects. Institute of International Educational Programs' Integration of Kyrgyz National University, Bishkek)

After revolution of 1905, in order to extinguish people's unrest in the central part of Russia, migration to Kyrgyzstan was very intensively not only from Russia but also from China Dungans and Uigurs Sinzyan after the suppression of Taipin revolt in China in 1877, regarding to the pass over of Iliy region to (Kuldja region) China.

As a result of defeat in 1916, Kyrgyzstan lost 30\% of it's population, $60 \%-70 \%$ of livestock, 130 thousand Kyrgyz migrated to East Turkestan (West China).

Geographic situation of Kyrgyzstan takes West (soviet/Russian) Tian-Shan. Eastern (major part) part of Tian-Shan takes China.

At the beginning of 18th century, Russia was necessary window to Europe. And Kyrgyzstan window to Asia Pacific Region at the beginning of 21 st century (see Table 1). According to Table 1, Torugart pass is unfinished window in the 21st century to the Asia Pacific Region.

Table 1

Compared Characteristics of Russian (18th century) and Kyrgyz (21st Century) Geopolitical Points and Environment

\begin{tabular}{|l|l|}
\hline Russia 18th century & Kyrgyzstan 21st century \\
\hline Saint-Petersburg & Naryn-Torugart \\
\hline Finish gulf & Kashkagaria \\
\hline Baltic sea & China \\
\hline Atlantic ocean & Pacific ocean \\
\hline
\end{tabular}

Central Asia is buffer zone between New Independent State and Asia Pacific Region. Kyrgyzstan as a part of that zone must react with flexibility to such tendency, also from another side. Kyrgyzstan has to find optimum balance between North-West and South-East. Kyrgyzstan is situated in the bordering zone four systematic big sides Russia(Eurasia), Islam, Western and Chinese. Geopolitical situation of Kyrgyzstan: On the North-political friendship Kazakhstan (Suyunbaev, 2005). Geopolitical grounds of development and security of Kyrgyzstan: global, regional and national aspects. Institute of International Educational Programs' Integration of Kyrgyz National University, Bishkek: (1) On the South-not stable Tajikistan, Afghanistan, Kashmir and Xinjiang (Kashgaria); (2) On the East-China with significant military and demographic potential; and (3) On the West-overpopulated and not stable Uzbekistan.

Possibilities and significantly vary forms of behavior of the small state according to the type of the international system in which they operate is dependent. During the cold war small states were Pawns in global rivalry for the status of a superpower (pawn sina global competition for super power status) (Hey, 2003, p. 1). Today they use more international prestige, than ever. Democratization of international relations has led to increase the role of small states as subjects in the international system. Owing to general strengthening it is international-rules of law and a global position of the United Nations the small states are equal in rights elements of the international structures and strengthen the foreign policy importance. In days of bipolar confrontation the small states supported "independence" a defensive method (Geser, 2004, p. 153). In modern international system "physical survival" it is in many instances well-off: the small states can protect the political integrity durably (Geser, 2004, p. 142). 


\section{Literature Review}

During a bipolar world order the small states because of division of the world by an ideological principle had limited enough freedom of actions. Strategic conditions today for the small states are represented in many respects more favorably, than in 1989: now the small states have significantly expanded spectrum of possibilities for the action. So the new world order, "which is shaped by means of set new and almost unlimited (multi) bilateral and (inter) regional attitudes between the states, associations of the states and the international organizations" (Schubert, 2005, p. 272), offers the big variety of possibilities for cooperation of the small states. The small Post-Soviet republic Kyrgyzstan can proclaim now "eternal friendship" with the Russian Federation and at the same time declare the American direction one of the foreign policy priorities, to be the partner of OTAN for the sake of the world and in parallel to base Shanghai Organization of Security together with the Russian Federation, the Peoples Republic of China and others Central Asian States.

One more structural element of a new world order is increasing globalization which is for the separate small state at the same time can mean both chance and a call. Local and regional progress influences to all actors of the international system. This trend, together with a phenomenon of the international terrorism, concerns to area of a security.

In the political, social and ecological also should become stronger: local decisions more are not effective, global decisions should be developed (Ruloff, 2005, p. 17). New position of threats and a general call to the international cooperation favor to a position of the small states in two ways: On the one hand, the material and military load lays mainly on great-power partners; on the other hand, existence of universal threat as, for example, the same international terrorism also conducts intensive inclusion of the small states as partners at negotiations by consideration of safety issues.

\section{Methodology}

Since the termination of the conflict between the West and the East conditions for formation of foreign policy of the small states have resolutely exchanged: The small states have a greater set of foreign policy options (decisions) for achievement of the objectives, than during the cold war.

But nevertheless the small states remain weak with limitation of the resources and deficiency of political and military power. Rigid realities of international relations show, that though the small states more are not objects of rivalry and a competition of great powers, they become with strengthening a role of regional powers by objects of their interests and policies. Essentially the role of the small and weak states in a world policy is limited: they pursue a policy more likely, rather than it's stated. Except for that influence on the small states is rendered with such factors as globalization, marginalization, a competition, increasing poverty, climate change and their consequences. The small state, thus, receives only varied possibilities, "if it by means of an ingenuity, tactical skill and mental abilities in a condition of globalization" (Geser, 2004, p. 153). Pressing question, whether is it time of "considerable opportunities" or "greater risks" for Kyrgyzstan? (Hey, 2003, p. 2).

\section{Results and Discussion}

For the years of independence the small state Kyrgyzstan owing to the open and active foreign policy managed to establish friendship with the Central Asian adjacent republics developed by the European countries, the Asian countries, including with the countries of the Islamic world, the major countries ATR, also with great powers Russia, China and the USA and to join in the every possible international organizations. But formal 
membership of the country in the numerous international organizations and an establishment of mutual relations is not the sufficient basis for judgment about successful foreign policy. The further measures on optimization of foreign policy activity of the country which should be undertaken.

For Kyrgyzstan with limitated of its resources and heavy process of economic transformation economic diplomacy has special value. It requires more precise definition of objectives and interests and search of various mechanisms for the achievement of these objectives. The special attention in this area should be given to cooperation Kyrgyz Republic with the international financial institutions. The subsequent proof-reading of cooperation of Kyrgyzstan with these organizations is proved.

Cooperation with economically advanced countries of the West and with Japan should remain a priority of the Kyrgyz foreign policy.

Strategically meaningful bilateral and multilateral cooperation with the Russian Federation and the Peoples Republic of China also remain as a main priority. The prospect of the Kyrgyz policy depends on how balance between these actors is maybe established.

Realization of the main priority of the Kyrgyz foreign policy - a safety-is connected with the further progress and an intensification of mutual relations with other states.

Speaking on foreign policy actors in Kyrgyzstan we can talk about triangle of actors: Russia, China, USA. At the moment should be expanded due to EU: EU is being realized in Central Asia some projects and programs, such as Trans-European mobility scheme for university studies (TEMPUS), Transport Corridor Europe-Caucasus-Asia (TRASECA), Interstate Oil and Gas Transport to Europe (INOGATE), Central Asia Drug Action Programme (CADAP), and Border Management Programme in Central Asia (BOMCA).

Final and adequate inclusion for Kyrgyzstan in the world community can occur only when it will manage strengthening internal process of political and economic transformation and to overcome internal political instability. As a controlling factor for successful realization of foreign policy priorities for the Kyrgyz Republic its internal political stability which keeps on unity of interests of the state and public colleges over the longer term acts. The successful policy defined by internal processes as the world practice shows, bears in itself success and in carrying out of complex extensive reforms in a society. In this context for Kyrgyzstan the thesis that only state effectively operating and constructed on rationales is capable to protect the population from negative influence of modern global threats of a security is important.

\section{Conclusion}

Summarizing the above-stated, it has to be noted the following. At a present stage of the progress Kyrgyzstan the same as also other states of the Central Asia, has appeared in a point of intersection of interests of some states and the influential international organizations. It is determined by rather new value of the region considered as recently opened "a raw pantry" world, and the geopolitics factors appreciably raising its value in conditions of deep transformation by all Systems of international relations. Without doubts, any world power which is participating fully in the Central-Asian policy, has well-defined vision of future for this region.

In brief, in opinion of authoritative scientist Nura Omarova (2004), they can be characterized as follows. The Russian "post-imperial" project is directed on restoration in region former influences (status quo), includes a binding to of the countries of region as one of tools to influence on updating of a rate of the USA on a world scene. Thus in view of realities of the present stage attempt to build new model of attitudes of former "center" with former allied "suburbs", where is done where there would be rather equal in rights account of interests of 
all sides. It occurs by creation and stage-by-stage realization of integration projects on the Post-Soviet space (Customs Union).

In turn, American "Neo-imperial" the project is aimed at "replacement" in region of geopolitics vacuum and creation of essentially new configuration in the world politics with a dominating role of the USA according to the concept of "a new world order". In this sense, the countries of region are considered the USA not as end in itself, however as one of means in the guarantor of own world domination.

Chinese "Assimilation" it is focused on renewal of attitudes having a certain historical context at a level of the center with "northern provinces".

In this context, European "integration" the project which bases the aspiration of the countries of the European Union to create a certain uniform space in territory of the Central-Asian region, causes the greatest sympathy. For this purpose, last 10-15 years from EU the specific projects uniting the states of the Central Asia which cannot be carried out without adequate multilateral cooperation between them are realized. Thereof, the incorporated Europe, in searches new geopolitics and a geo-economics situation in the world space, actively assists a deepening of processes of integration and self-identification of the states of the Central Asia.

\section{References}

Geser, H. (2004). Uber die historische Entwicklung und Stellung kleiner Staaten. In E. Busek \& W. Hummer (Eds.), Der Kleinstaat als Akteur in den internationalen Beziehungen (pp. 133-154). Liechtenstein. Politische Schriften. Band 39. Schaan: Verlag der Liechtensteinischen Akademischen Gesellschaft.

Hey, J. A. K. (2003). Introducing small state foreign policy. In Ders. (Ed.), Small states in world politics (pp. 1-11). Boulder: Explaining Foreign Policy Behavior.

Omarov, N. M. (2004). Kyrgyzstan European Union: Evolution and priorities of cooperation at the end of XX century and beginning of XXI century. Central Asia at the foreign policy of European Union//under the publication of J.U. Ibrasheva. Almaty.

Ruloff, D. (2005). Welche Weltordnung? Eine Einfuhrung. In D. Ruloff (Hrsg.), Welche Weltordnung (pp. 11-32). Schweizerisches Institut fur Auslandsforschung: Verlag Ruegger.

Schubert, K. (2005). Deutschland und seine Ausenpolitik im europaischen und transatlantischen Kontext. "Normalisierung" oder “soft power"? In A. Gawrich \& H. J. Lietzamann (Eds.), Politik und Geschichte. “Gute Politik” und ihre Zeit (pp. 271-292). Munster: Verlag Westfalisches Dampfboot.

Suyunbaev, M. (2005). Geopolitical grounds of development and security of Kyrgyzstan: Global, regional and national aspects. Institute of International Educational Programs' Integration of Kyrgyz National University, Bishkek. 